\title{
Varroa destructor is the main culprit for the death and reduced populations of overwintered honey bee (Apis mellifera) colonies in Ontario, Canada*
}

\author{
Ernesto GuZMÁn-NovoA ${ }^{1}$, Leslie Eccles ${ }^{1}$, Yireli CALVETE ${ }^{2}$, Janine McGowAN ${ }^{1}$, \\ Paul G. KELlY ${ }^{1}$, Adriana CorREA-BENíteZ ${ }^{2}$ \\ ${ }^{1}$ Department of Environmental Biology, University of Guelph, Guelph, ON, Canada N1G 2W1 \\ ${ }^{2}$ Departamento de Esp. Prod. No Trad., FMVZ, UNAM, Cd. Universitaria, Mexico DF 04510, Mexico
}

Received 16 March 2009 - Revised 24 July 2009 - Accepted 7 September 2009

\begin{abstract}
The relative effect of parasite levels, bee population size, and food reserves on winter mortality and post winter populations of honey bee colonies was estimated. More than 400 colonies were monitored throughout three seasons in Ontario, Canada. Most of the colonies were infested with varroa mites during the fall (75.7\%), but only $27.9 \%$ and $6.1 \%$ tested positive to nosema disease and tracheal mites, respectively. Winter colony mortality was $27.2 \%$, and when examined as a fraction of all morbidity factors, fall varroa mite infestations were the leading cause of colony mortality (associated to $>85 \%$ of colony deaths), followed by fall bee populations and food reserves. Varroa-infested colonies, with weak populations and low food reserves in the fall, significantly decreased spring colony populations, whereas varroa infestations and Nosema infections in the spring, significantly decreased bee populations by early summer. Overall, results suggest that varroa mites could be the main culprit for the death and reduced populations of overwintered honey bee colonies in northern climates.
\end{abstract}

winter colony mortality / CCD / Varroa destructor / bee populations / Ontario

\section{INTRODUCTION}

Beekeepers, crop growers, authorities, scientists and the general public are all concerned and alarmed with the mysterious dieoffs of honey bee (Apis mellifera) colonies that have occurred during the last three years in many countries around the world. The phenomenon has been named colony collapse disorder (CCD) in the USA; many suspects have been suggested as potential culprits of these losses, but no clear explanation has yet been found (vanEngelsdorp et al., 2008). So far, no name or causes have been proposed for the higher than normal winter colony losses beekeepers are experiencing in Canada

Corresponding author: E. Guzmán-Novoa, eguzman@uoguelph.ca

* Manuscript editor: Yves Le Conte
(Kevan et al., 2007). In Ontario, 35\% of the province's colonies died over the winter of 2006-2007 (McRory, 2007), and 32\% of them died again during the winter of 2007-2008 (Guzmán-Novoa, 2008). This substantial number of colony losses is unprecedented in the province and is three times the expected winter loss during average years.

Although the causes of the record mortality of honey bee colonies remains undetermined, most scientists agree that it is likely due to a combination of several factors ranging from viruses, parasites and diseases, to singlesource diets, compromised disease resistance, inclement weather, and pesticides (Stankus, 2008). It is known for example, that the parasitic mites Varroa destructor and Acarapis woodi are causes of colony mortality and thus several synthetic miticides have been used successfully in their control (De Jong, 1997; 
Wilson et al., 1997; Ellis, 2001). However, mite resistance to the active ingredients in miticides is now widespread in Europe, the USA and Canada (Elzen et al., 1998, 1999; Milani, 1999; Sprefacio et al., 2001; Elzen and Westervelt, 2002; Thompson et al., 2002; Skinner et al., 2003). Therefore, it is possible that mite populations are more difficult to control and are causing more damage to colonies in recent years. Organic miticides such as formic and oxalic acid have been used more in recent years, but it is possible that these products may not provide enough protection against the above-mentioned parasitic mites.

High levels of nosema disease (Nosema apis) may also cause colony mortality during winter or poor colony buildup during spring (Bailey and Ball, 1991). Nosema disease is endemic in honey bee colonies in Ontario, but its association with colony losses in the province remains unknown. Additionally, a new Nosema species, Nosema ceranae, was recently found to infect Apis mellifera colonies (Fries et al., 2006; Huang et al., 2007). The presence of Nosema ceranae was confirmed in Canada in 2007 (Williams et al., 2008). This new species of Nosema has been linked to the collapse of thousands of colonies in parts of Europe (Higes et al., 2006, 2007, 2008; Martín-Hernández et al., 2007) and could likely be a suspect of colony losses in Ontario. Other causes of winter colony mortality may include starvation due to insufficient food reserves and weak colony populations during winter (Free and Racey, 1968; Stankus, 2008; vanEngelsdorp et al., 2008).

The objective of this study was to investigate the relative effect of five factors that presumably could contribute to winter colony mortality and to decreased bee populations in the spring and summer. Specifically, we looked at low food reserves, low bee population, nosema disease and infestation of varroa and tracheal mites in commercial honey bee colonies.

\section{MATERIALS AND METHODS}

A total of 408 colonies located in six different regions of southern Ontario, Canada, were randomly selected to assess presumed causes of honey bee mortality and correlate them with colony seasonal conditions and die offs. The regions where colonies were located included the counties of Norfolk, Six Nations, Wellington, Grey, Niagara and Middlesex. Selected colonies belonged to beekeepers that did not apply any disease control procedures during the duration of the study (late October 2007 to late June 2008). Previous to being selected, most colonies had been treated with different miticides within the last 12 months, but none of them had been treated against nosema disease.

The selected colonies were evaluated and sampled in the fall 2007 (late October to mid November) spring 2008 (late March to mid April), and early summer 2008 (mid to late June) to obtain individual information of factors that presumably affect colony survivorship and size of bee populations. On each occasion, the experimental colonies were carefully opened without using smoke to avoid colony disturbance, and the number of combs covered by bees were counted to estimate their population (Nasr et al., 1990). After counting frames with bees, samples of ca. 300 workers were collected from the brood chambers and placed in jars containing $70 \%$ ethanol until analyzed. Colonies were also weighed using a spring scale (Salter 235, London, England; $\pm 500 \mathrm{~g}$ accuracy; $150 \mathrm{~kg}$ capacity), and the weight of the equipment and bees were subtracted from the total colony weight. Weight was used as an indicator of food reserves since most of the weight of colonies in the fall corresponds to food reserves (Szabo, 1982).

The worker bee samples were analyzed for presence or apparent absence of tracheal mites, varroa mites and spores of Nosema spp., as well as for levels of these parasites as per Shimanuki and Knox (2000). Colony die-offs were recorded in the spring and summer, when surviving colonies were assessed again for the same five factors.

Colonies were subcategorized into two levels: high and low, according to their fall condition for food reserves (high $>23.6 \mathrm{~kg}$; low $<23.6 \mathrm{~kg}$ ), bee population (high $\geqslant 8$ frames with bees; low $\leqslant 7$ frames with bees) and varroa mite levels (high $\geqslant$ 5.2 ; low $\leqslant 5.1$ mites per 100 bees). High and low values were arbitrarily established by being either above (for high values) or below (for low values) the means obtained for these variables from all colonies used in the study $(n=408)$. It was not possible to subcategorize colonies according to infestation levels of Acarapis woodi and infection levels caused by Nosema spp., because of low parasitic rates and 
Table I. Mean fall, spring, and summer conditions ( \pm SE) of honey bee colonies in Ontario, Canada, for factors that could be associated to colony mortality and low spring and summer bee populations.

\begin{tabular}{llll}
\hline Factor & \multicolumn{1}{c}{ Fall $^{5}$} & \multicolumn{1}{c}{ Spring $^{5}$} & Summer $^{5}$ \\
\hline Bee population $^{1}$ & $7.4 \pm 0.1$ & $4.3 \pm 0.2$ & $15.8 \pm 0.5$ \\
Food reserves $(\mathrm{kg})_{\text {Varroa mite infestation }^{2}}$ & $23.6 \pm 0.4$ & $12.5 \pm 0.5$ & $42.6 \pm 2.5$ \\
Tracheal mite infestation $^{3}$ & $1.0 \pm 0.5$ & $3.1 \pm 0.6$ & $1.5 \pm 0.2$ \\
Nosema $_{\text {infection }}{ }^{4}$ & 9804 & $0.8 \pm 0.2$ & $1.1 \pm 0.4$ \\
& \pm 4688 & 3108199 & 1142000 \\
& & \pm 327722 & \pm 118200 \\
\hline
\end{tabular}

${ }^{1}$ Number of frames covered by bees per hive; ${ }^{2}$ number of mites per $100 \mathrm{bees} ;{ }^{3}$ number of parasitized bees in $100 ;{ }^{4}$ number of spores per bee. ${ }^{5} N=408,297$, and 278 for fall, spring, and summer, respectively.

low number of colonies affected by these pathogens in the fall.

Data were analyzed using descriptive statistics, paired comparison tests (Mann-Whitney U tests to compare data from dead and live colonies; Chi square and contingency table analysis to compare mortality counts by condition or by region) and Spearman rank correlation analyses. Data on percentage of varroa and tracheal mite infestation were arcsine square-root transformed before being subjected to analyses of variance and Fisher's protected LSD tests. This transformation was necessary to normalize data before analysis.

\section{RESULTS}

\subsection{Mortality rates and colony conditions}

Out of 408 colonies evaluated in the fall 2007, 111 were dead in the spring 2008 $(27.2 \%)$, and 19 additional colonies died between the spring and early summer of 2008 , for a total annual mortality rate of $31.9 \%$. On average, colonies lost $42 \%$ of their bee populations and $47 \%$ of their food reserves during winter. However, colony populations and food reserves increased $267 \%$ and $241 \%$, respectively, by early summer (Tab. I). The infestation levels of varroa mites decreased during the winter and early summer, whereas tracheal mite infestation levels remained stable throughout the study period. Conversely, Nosema infection levels increased 317 fold after the winter to more than 3.1 million spores per bee, but decreased to slightly over 1.1 million spores per bee by early summer (Tab. I).
Colonies that died during the winter had significantly lower bee populations and food reserves as well as higher mite infestation levels than surviving colonies during the previous fall $(P<0.001)$. No differences in Nosema infection levels were found between colonies that died and those that survived (Tab. II).

\subsection{Colony mortality and factors by region}

Colony mortality rates were high in three regions (Norfolk 41\%, Six Nations 37\%, and Wellington 39\%) and significantly $(P<$ 0.0001 ) lower in other three regions (Grey $11 \%$, Niagara $8 \%$, and Middlesex $2 \%$ ). These corresponded closely with the levels of varroa infestation, since they were high in the same three regions (Norfolk $6.7 \pm 0.6 \%$, Six Nations $5.0 \pm 0.9 \%$, and Wellington $8.1 \pm 0.9 \%$ ) and significantly $(P<0.0001)$ lower in the other three regions (Grey $0.3 \pm 0.7 \%$, Niagara $0.9 \pm 0.1 \%$, and Middlesex $1.6 \pm 0.3 \%$ ). No significant differences among regions were found for fall colony food reserves $\left(F_{5,402}=2.08\right.$, $P=0.085)$, bee populations $\left(F_{5,402}=2.14\right.$, $P=0.059)$, Nosema infection levels $\left(F_{5,402}=\right.$ $0.68, P=0.636)$, and tracheal mite infestation levels $\left(F_{5,402}=1.34, P=0.247\right)$.

\subsection{Relative effect of different factors on colony mortality}

When examined as a fraction of all morbidity factors, fall varroa mite infestation was 
Table II. Mean fall conditions ( \pm SE) of 408 honey bee colonies found alive or dead the following spring in Ontario, Canada, for different factors that could be associated to colony mortality and low spring and summer bee populations. $P$ based on Mann-Whitney $\mathrm{U}$ tests.

\begin{tabular}{llll}
\hline Factor & \multicolumn{1}{c}{ Alive } & \multicolumn{1}{c}{ Dead } & \multicolumn{1}{c}{$P$} \\
\hline Bee population $^{1}$ & $8.0 \pm 0.1$ & $5.9 \pm 0.2$ & $<0.0001$ \\
Food reserves $(\mathrm{kg})_{\text {Varroa mite infestation }^{2}}^{25.4 \pm 0.5}$ & $2.9 \pm 0.2$ & $11.0 \pm 0.9$ & $<0.0001$ \\
Tracheal mite infestation $^{3}$ & $0.2 \pm 0.1$ & $3.1 \pm 1.3$ & $<0.0001$ \\
Nosema $_{\text {infection }}{ }^{4}$ & 6734 & 18018 & 0.001 \\
& \pm 3238 & \pm 14923 & \\
\hline
\end{tabular}

${ }^{1}$ Number of frames covered by bees per hive; ${ }^{2}$ number of mites per 100 bees $;{ }^{3}$ number of parasitized bees in $100 ;{ }^{4}$ number of spores per bee.

the leading cause of winter colony mortality, followed by fall bee populations and food reserves (Tab. III). All the factors studied had a significant effect on colony mortality $(P<$ 0.001), except Nosema infections.

More than $23 \%$ of the studied colonies were affected by a single factor, $38.2 \%$ by two and $21.8 \%$ by three. Varroa mites were part of 11 of the 17 conditions into which colonies were categorized, which when summed, related to > $85 \%$ of the total cases of colony mortality. The conditions of single or combined factors that showed a higher association with total colony mortality were: (1) the combination of varroa mite presence, low bee population and low food reserves $(25.2 \%)$, (2) the combination of varroa mite and nosema disease presence, low bee population and low food reserves $(12.6 \%)$, (3) the combination of varroa mite presence and low food reserves $(10.8 \%)$, and (4) the sole presence of varroa mites $(10.8 \%)$. Only one entirely unaffected colony (for the factors studied) died out of 21 .

\subsection{Relative effect of different factors on colony populations}

Fall colony food reserves and bee populations were significantly and positively correlated with the number of frames covered by bees in spring colonies, whereas varroa mite infestations showed a negative correlation with this variable $(r=0.60, r=0.49, r=-0.29$, respectively; $n=297, P<0.0001)$. Significant positive correlations were also found between early summer colony populations and the number of frames covered by bees in the spring ( $r=0.29 ; n=278, P<0.001)$. Spring levels of varroa mites and Nosema infection negatively correlated with early summer bee populations $(r=-0.29, r=-0.27$, respectively; $n=278, P<0.001)$. Tracheal mite levels did not correlate with bee population variables.

\section{DISCUSSION}

\subsection{Mortality rates and colony conditions}

The winter mortality rate of the colonies monitored in this study was $27.2 \%$, close to the $32 \%$ reported by Ontario beekeepers in a survey (Guzmán-Novoa, 2008). Furthermore, if the 19 additional colonies that died between the spring and early summer 2008 are added to the equation, the annual mortality rate increases to $31.9 \%$. Our results on colony mortality thus seem to reflect what occurred across the province of Ontario.

Colonies lost population and weight during winter and gained weight during the spring. Parasitic mite levels decreased over the winter, likely as a consequence of the lack of sufficient bee brood to reproduce (in the case of varroa mites) and because of the lack of young bees to parasitize (in the case of tracheal mites) (Bailey and Ball, 1991). The fact that the percentage of varroa-infested bees had decreased by the summer may be misleading. It is probable that in the presence of brood, many 
Table III. Effect of different fall factors on winter mortality for 408 honey bee colonies found alive or dead the following spring in Ontario, Canada. $P$ based on Chi square tests.

\begin{tabular}{lccccc}
\hline Factor & Condition $^{5}$ & No. alive & No. dead & \% Mort/Total & \\
\hline Bee population $^{1}$ & Low & 122 & 77 & 69.4 & $<0.0001$ \\
& High & 175 & 34 & & \\
Food reserves (kg) & Low & 140 & 75 & 67.6 & $<0.001$ \\
& High & 157 & 36 & & \\
Varroa mite & Positive & 214 & 95 & 85.6 & $<0.01$ \\
infestation $^{2}$ & Negative & 83 & 16 & & \\
Tracheal mite $_{\text {infestation }^{3}}$ & Positive & 13 & 12 & 10.8 & 0.0159 \\
Nosema disease $^{4}$ & Negative & 284 & 99 & & \\
& Positive & 76 & 38 & 34.2 & 0.0833 \\
& Negative & 221 & 73 & & \\
\hline
\end{tabular}

${ }^{1}$ Number of frames covered by bees per hive; ${ }^{2}$ number of mites per $100 \mathrm{bees} ;{ }^{3}$ number of parasitized bees in $100 ;{ }^{4}$ number of spores per bee; ${ }^{5}$ colonies were classified as having low or high food reserves or bee populations if the values for these variables were below (for low) or above (for high) the means obtained from all colonies used in the study (low $<23.6 \mathrm{~kg}$; high $>23.6 \mathrm{~kg}$ for food reserves; low $\leqslant 7$ frames with bees; high $\geqslant 8$ frames with bees for bee population; $n=408) ;{ }^{6}$ percent mortality calculated from the total number of colonies that died during the winter $(n=111)$.

mites had been in capped brood cells and actually the mite load per colony had increased as has been shown in studies on mite population dynamics (Fries et al., 1994; Martin, 1998; Wilkinson and Smith, 2002). The low parasitic levels of Acarapis woodi and the low number of colonies infested with this mite could be interpreted, at least partially, as a consequence of the many years of intensive selection for tracheal mite resistance conducted by beekeepers and scientists in Ontario (Nasr et al., 2001).

The most striking result regarding variation of the factors studied was the explosive growth in Nosema infection levels (317-fold) after the winter. This dramatic increase in Nosema infection in the spring may have occurred because when colonies recommence their brood production, young bees become infected with Nosema spores as they clean contaminated comb cells for the queen to lay eggs (Fries, 1997).

\subsection{Colony mortality and factors by region}

Varroa mite infestation levels varied significantly among regions and showed a similar pattern to that of mortality rates. The highest and lowest varroa infestation rates coincided with the same regions in which colony mortality rates were high and low, respectively. These results as well as those discussed below, strongly suggest that varroa mites may be the main cause associated with the mortality of the colonies studied. Ontario is a representative beekeeping region of northern climates; therefore, the importance that varroa mites seem to have on the survivorship of overwinterd colonies in Ontario may be similar in other northern regions of the world.

\subsection{Relative effect of different factors on colony mortality}

Nosema disease and tracheal mites were apparently the least damaging factors, while higher fatality cases were associated with varroa mites either alone or in combination with other factors $(>85 \%)$, followed by low bee populations associated to other factors (> 69\%). These results would be expected for varroa mites and for weak colonies, since it has been shown that these two factors can be directly associated to overwintered colony losses (Downey et al., 2000). However, they do not necessarily mean that Nosema and Acarapis woodi are harmless parasites. Very few colonies were infested with tracheal mites 
(only $6.1 \%$ ), which could have accounted for their low effect on colony mortality in this study. In the case of nosema disease, although a considerable number of colonies were Nosema positive (114 colonies out of 408 , or $27.9 \%$ ), these colonies had low fall infection levels (9804 \pm 4688 spores per bee).

The relative weight of nosema disease in the mortality of overwintered colonies is a controversial matter. Higes et al. (2006, 2007, 2008) and Martín-Hernández et al. (2007) attribute a major effect to Nosema infections in the mortality of colonies. However, there is no conclusive evidence to affirm that Nosema is an important factor in the recent honey bee die-offs worldwide (Stankus, 2008). Certainly our results do not support the arguments of Higes et al. (2006, 2007, 2008) and MartínHernández et al. (2007). It is possible however, that the same honey bee parasites may cause varying degrees of damage depending on their geographical locations. It is also possible that other factors not studied could have contributed to the observed mortality cases, although their contribution would have been insignificant considering that only one entirely unaffected colony (for the factors studied) died out of 21 .

It is relevant to highlight that surviving colonies had mean varroa infestation levels lower than $3 \%(2.9 \pm 0.2 \%)$, and $5 \%$ or lower for surviving colonies in the low infested category during the fall. These fall varroa infestation rates are lower than previously published acceptable mite loads (Delaplane and Hood, 1997; Currie and Gatien, 2006). Perhaps acceptable mite loads need to be re-assessed downwards.

\subsection{Relative effect of different factors on colony populations}

The effect the factors studied had on worker bee life span during winter can be inferred from the results on bee population in the spring 2008; specifically those from colonies that were positive to any of the three parasites, or from colonies that had low bee populations and weight in the fall 2007. Results suggest that varroa mites significantly reduced colony bee populations, which is in agreement with previous studies (Strange and Shepard, 2001; Murilhas, 2002; Martin, 2001; Sumpter and Martin, 2004). Nosema disease and tracheal mites did not show a significant effect on bee populations, which could be explained by the reasons discussed above. These results stress the importance of maintaining minimum varroa mite populations in the fall. Low colony population and food reserves also negatively affected spring populations of bees, which in turn could have an effect on bee populations in the summer, and consequently on colony productivity.

Varroa mites, Nosema, and low bee populations in the spring were associated to slower colony development. Colonies that tested negative or had low levels of the above parasites, as well as colonies that were strongly populated in the spring, had significantly more bees in early summer than colonies with high levels of these pathogens or that were weakly populated in the spring. These results support the conclusion that varroa mites, nosema disease, and weak spring colony populations, compromise colony buildup.

The results of this study are not conclusive because the colony conditions for the five factors analyzed were not controlled. Despite its limitations, field studies like this are valuable because a large number of colonies were evaluated under natural conditions, as they were managed by beekeepers, which might shed light on the causes of winter colony losses. Overall, results suggest that varroa mites could have a high and negative impact on the survivorship of overwintered honey bee colonies. Moreover, these mites along with Nosema infections and weakly populated colonies might significantly restrain the growth of honey bee colonies during the spring in northern climates.

\section{ACKNOWLEDGEMENTS}

Conducting this study was made possible by the efforts of an extensive list of collaborators. The following people provided substantial contribution: Brian Lacey, Laura Campbell, Rodrigo León, Raquel Mijares, and Nancy Bradbury sampled colonies and diagnosed bee diseases. Otillie 
Welsh provided training in tracheal mite diagnosis. The Technology Transfer Team of the Ontario Beekeepers' Association (OBA) and Doug McRory, the provincial apiarist, provided assistance in countless ways. We are particularly grateful to the participating beekeepers as well as to the NSERC, the OBA, the IICA, and the Ontario Ministry of Agriculture, Food and Rural Affairs for funding this study.

Varroa destructor est le principal responsable de la mort et de la réduction des populations de colonies d'abeilles (Apis mellifera) après hivernation en Ontario, Canada.

Apis mellifera / mortalité post-hivernale / Varroa destructor / syndrome d'effondrement des colonies / Ontario

\section{Zusammenfassung - Varroa destructor ist die} Hauptursache für Winterverluste und für die Abnahme der Bienenpopulation in überwinternden Honigbienenvölkern in Ontario, Kanada. Der relative Effekt des Befallsgrades, der Volksstärke und der Futtervorräte auf die Überwinterungsverluste und die Auswinterungstärke von Honigbienenvölkern wurde abgeschätzt. Über 400 Bienenvölker in sechs verschiedenen Regionen in Ontario, Kanada, wurden im Herbst, Frühjahr und im Frühsommer kontrolliert. Die meisten Völker waren im Herbst mit Varroamilben befallen $(75,7 \%$ ), aber nur $6,1 \%$ and $27,2 \%$ der Völker wurden positiv auf Tracheenmilben bzw. Nosemose getestet. Die Wintermortalität lag bei $27,2 \%$, wobei die überlebenden Völker etwa die Hälfte ihrer Bienen und Futtervorräte verloren hatten. Während der Varroabefall über den Winter abnahm, stieg der Nosemabefall um das 317-fache auf mehr als 3,1 Millionen Sporen pro Biene im Frühjahr an (Tab. I). Allerdings wurden keine Unterschiede im Nosemabefall zwischen zusammengebrochenen und überlebenden Bienenvölkern gefunden. Bienenvölker, die während des Winters eingegangen waren, hatten signifikant weniger Bienen und Futtervorräte sowie einen höheren Milbenbefall im vorherigen Herbst als überlebende Völker $(P<0,001$; Tab. II). Bei den Mortalitätsraten gab es Unterschiede zwischen den sechs Regionen: Die drei Regionen mit der höchsten Mortalitätsrate waren signifikant stärker mit Varroamilben befallen als die drei Regionen mit den geringsten Verlusten $(P<0,0001)$. Wenn man die einzelnen Faktoren bzgl. ihrer Bedeutung für die Winterverluste beurteilt, so waren die meisten Völkerverluste mit dem Varroabefall korreliert $(>85 \%)$, gefolgt von der Bienenpopulation $(>69 \%)$ und den Futtervorräten (> $67 \%$; Tab. III). Die Futtervorräte und die Bienenpopulation im Herbst waren signifikant positiv korreliert mit der Anzahl an bienenbesetzten Waben im Frühjahr, während der Varroabefall mit dieser Variablen negativ korreliert war $(P<0,0001)$. Auch zwischen der Bienenpopulation im Frühsommer und der Anzahl an bienenbesetzten Waben im Frühjahr gab es signifikant positive Korrelationen $(P<0,001)$. Der Frühjahrsbefall mit Varroamilben und der Nosemabefall waren dagegen negativ korreliert mit der Bienenpopulation im Sommer $(P<0,001)$.

Insgesamt zeigen die Ergebnisse, dass Varroamilben große und negative Auswirkungen auf die Überlebensrate von überwinternden Bienenvölkern haben. Darüber hinaus könnte eine Kombination von Varroabefall, Nosemabefall und schwachen Völkern die Frühjahrsentwicklung von Bienenvölkern in nördlichen Klimazonen signifikant beeinträchtigen. Diese Ergebnisse betonen die Bedeutung einer geringen Varroapopulation im Herbst verbunden mit der Einwinterung von gut gefütterten und starken Bienenvölkern.

\section{Winterverluste / CCD / Varroa destructor / Bie- nenpopulationen / Ontario}

\section{REFERENCES}

Bailey L., Ball B.V. (1991) Honey Bee Pathology, Academic Press, San Diego.

Currie R.W., Gatien P. (2006) Timing acaricide treatments to prevent Varroa destructor (Acari: Varroidae) from causing economic damage to honey bee colonies, Can. Entomol. 138, 238-252.

De Jong D. (1997) Mites: Varroa and other parasites of brood, in: Morse R.A. and Flottum K. (Eds.), Honey bee pests, predators, and diseases, Root Publishing, Medina, Ohio, pp. 279-327.

Delaplane K.S., Hood W.M. (1997) Effects of delayed acaricide treatment in honey bee colonies parasitized by Varroa jacobsoni and a late-season treatment threshold of the south-eastern USA, J. Apicult. Res. 36, 101-108.

Downey D.L., Higo T., Winston M.L. (2000) Honey bee colony mortality and productivity with single and dual infestations of parasitic mite species, Insect. Soc. 47, 171-176.

Ellis M.D. (2001) Chemical control of varroa mites, in: Webster T.C., Delaplane K.S. (Eds.), Mites of the honey bee, Dadant and Sons, Hamilton, Illinois, pp. 179-196.

Elzen P.J., Baxter J.R., Spivak M., Wilson W.T. (1999) Amitraz resistance in varroa: new discovery in North America, Am. Bee J. 139, 362.

Elzen P.J., Eischen F.A., Baxter J.R., Elzen G.W., Wilson W.T. (1998) Detection of resistance in US in Varroa jacobsoni Oud. (Mesostigmata: Varroidae) to the acaricide fluvalinate, Apidologie 30, 13-17.

Elzen P.J., Westervelt D. (2002) Detection of coumaphos resistance in Varroa destructor in Florida, Am. Bee J. 142, 291-292. 
Free J.B., Racey P.A. (1968) The effect of the size of honeybee colonies on food consumption, brood rearing and the longevity of the bees during winter, Entomol. Exp. Appl. 11, 241-249.

Fries I. (1997) Protozoa, in: Morse R.A., Flottum K. (Eds.), Honey bee pests, predators, and diseases, Root Publishing, Medina, Ohio, pp. 57-76.

Fries I., Camazine S., Sneyd J. (1994) Population dynamics of Varroa jacobsoni: a model and a review, Bee World 75, 4-28.

Fries I., Martin R., Meana A., Garcia R., Higes M. (2006) Natural infections of Nosema ceranae in European honey bees, J. Apicult. Res. 45, 230233.

Guzmán-Novoa E. (2008) Mortality causes of overwintered honey bee colonies in Ontario, Ontario Bee J. 27, 22-23.

Higes M., García P., Martín R., Meana A. (2007) Experimental infection of Apis mellifera honeybees with Nosema ceranae (Microsporidia), J. Invertebr. Pathol. 94, 211-217.

Higes M., García P., Martín-Hernandez R., Biotas C., Bailon E.G., Gonzalez-Porto A.V., Barrios L., del Nozal M.J., Bernal J.L., Jimenez J.J., Palencia P.G., Meana A. (2008) How natural infection by Nosema ceranae causes honeybee colony collapse, Environ. Microbiol. 10, 2659-2669.

Higes M., Martín R., Meana A. (2006) Nosema ceranae, a new microsporidian parasite in honeybees in Europe, J. Invertebr. Pathol. 92, 93-95.

Huang W., Jiang J., Chen Y., Wang C. (2007) A Nosema ceranae isolate from the honeybee Apis mellifera, Apidologie 38, 30-37.

Kevan P.G., Guzmán-Novoa E., Skinner A., van Englesdorp D. (2007) Colony collapse disorder in Canada: do we have a problem? Hive Lights 20, 14-16.

Martin S. (1998) A population model for the ectoparasitic mite Varroa jacobsoni in honey bee (Apis mellifera) colonies, Ecol. Model. 109, 267-281.

Martin S. (2001) The role of Varroa and viral pathogens in the collapse of honey bee colonies, J. Appl. Ecol. 53, 105-112.

Martín-Hernández R.H., Meana A., Prieto L., Martínez A., Garrido E., Higes M. (2007) Outcome of colonization of Apis mellifera by Nosema ceranae, Appl. Environ. Microb. 73, 6331-6338.

McRory D. (2007) Monthly report for November 2007, The Sting 25, 24-25.

Milani N. (1999) The resistance of Varroa jacobsoni Oud. to acaricides, Apidologie 30, 229-234.

Murilhas A.M. (2002) Varroa destructor infestation impact on Apis mellifera carnica capped worker brood production, bee population and honey storage in a Mediterranean climate, Apidologie 33, 271-281.
Nasr M.E., Otis G.W., Scott-Dupree C. (2001) Resistance to Acarapis woodi by honey bees (Hymenoptera: Apidae): divergent selection and evaluation of selection progress, J. Econ. Entomol. 94, 332-338.

Nasr M.E., Thorp R.W., Tyler T.L., Briggs D.L. (1990) Estimating honey bee (Hymenoptera: Apidae) colony strength by a simple method: measuring cluster size, J. Econ. Entomol. 83, 748-754.

Shimanuki H., Knox D.A. (2000) Diagnosis of Honey Bee Diseases, U.S. Department of Agriculture, Agriculture Handbook No. AH-690, p. 61

Skinner A., Tam J., Melin S. (2003) Monitoring for fluvalinate resistant varroa mites and coumaphos efficacy trials in honey bee colonies in Ontario, The Sting 21, 23-25.

Sprefacio M., Eordegh F.R., Bernardinelli I., Colombo M. (2001) First detection of strains of Varroa destructor resistant to coumaphos. Results of laboratory tests and field trials, Apidologie 32, 49-55.

Stankus T. (2008) A review and bibliography of the literature of honey bee Colony Collapse Disorder: a poorly understood epidemic that clearly threatens the successful pollination of billions of dollars of crops in America, J. Agr. Food Inform. 9, 115143.

Strange J.P., Sheppard W.S. (2001) Optimum timing of miticide applications for control of Varroa destructor (Acari: Varroidae) in Apis mellifera (Hymenoptera: Apidae) in Washington State, USA, J. Econ. Entomol. 94, 1324-1331.

Sumpter D.J.T., Martin S.J. (2004) The dynamics of virus epidemics in Varroa-infested honey bee colonies, J. Anim. Ecol. 73, 51-63.

Szabo T.I. (1982) Phenotypic correlations between colony traits in the honey bee, Am. Bee J. 122, 711-716.

Thompson H.M., Brown M.A., Ball R.F. Bew M.H (2002) First report of Varroa destructor resistance to pyrethroids in UK, Apidologie 33, 357-366.

vanEngelsdorp D., Hayes J., Underwood R.M., Pettis J. (2008) A survey of honey bee colony losses in the U.S., fall 2007 to spring 2008, PloS ONE 3, $1-6$.

Wilkinson D., Smith G.C. (2002) A model of the mite parasite, Varroa destructor, on honeybees (Apis mellifera) to investigate parameters important to mite population growth, Ecol. Model. 148, 263 275.

Williams G.R., Shafer A.B.A., Rogers R.E.L., Shutler D., Stewart D.T. (2008) First detection of Nosema ceranae, a microsporidian parasite of European honey bees (Apis mellifera), in Canada and central USA, J. Invertebr. Pathol. 97, 189-192.

Wilson W.T., Pettis J.S., Henderson C.E., Morse R.A. (1997) Tracheal mites, in: Morse R.A. and Flottum K. (Ed.), Honey bee pests, predators, and diseases, Root Publishing, Medina, Ohio, pp. 253-277. 